International Journal of Physical Sciences and Engineering
Available online at http://sciencescholar.us/journal/index.php/ijpse
Vol. 2 No. 2, August 2018, pages: 50 67
e-ISSN : 2550-6943, p-ISSN : 2550-6951
https://doi.org/10.29332/ijpse.v1n2.146

\title{
Comparison of Studies through Laboratory Tests to Loan Material (ballast) of San Jose and AGRE S.A. Quarries Treated with Asphalt Emulsion or Cement
}

\author{
Cross \\ Maria Isabel Zambrano Meza a , Edwin Alexander Rodriguez Veliz b, Cesar Augusto Veliz Mendoza c, \\ Ricardo Andres Cedeno Delgado d, Gema Flores Ormaza e \\ Article history: Received 9 February 2018, Accepted in revised form 1 June 2018, Approved 12 July 2018, \\ Available online 25 July 2018

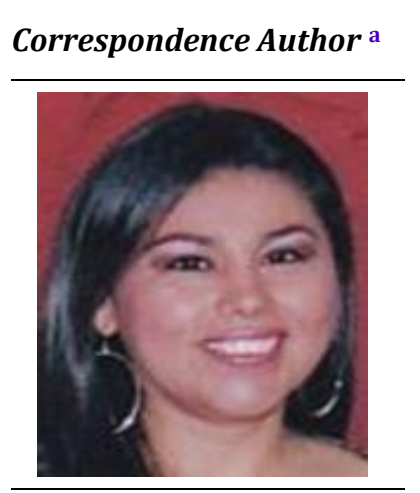 \\ Keywords \\ Ballast; \\ Materials; \\ Pavements; \\ Quarries;

\begin{abstract}
In the construction of pavement, structures are determined by granular materials treated with asphalt emulsion in the pavements, in the structure of the pavements is very common to find unsuitable materials which generate both in the constructive and economic environment various types of inconveniences. The pavement structures are made up of different layers, each of which fulfills a certain function. The treatment of the material helps to reduce the cost of the pavement structures, obtaining improvements in their behavior and economic results in the construction of the same. What is intended in this research is the treatment of the selected material combined with asphalt emulsion, therefore, that can be used both as a base or sub-base within the pavement structures. For the analysis of the behavior of the selected material, the San José and AGRE S.A quarries were taken, in order to determine their own characteristic variants and thus demonstrate whether stated material meets the technical specifications for incorporation in the construction of the pavement structures.
\end{abstract}

Sub-base;

e-ISSN: 2550-6943, p-ISSN: 2550-6951 @ Copyright 2018. The Author. SS Journals Published by Universidad Técnica de Manabí. This is an open-access article under the CC BY-SA 4.0 license (https://creativecommons.org/licenses/by-sa/4.0/) All rights reserved.

a MsC, Candidate to Ph.D., Engineering, Faculty of Mathematical, Physical and Chemical Sciences, Universidad Tecnica de Manabi, Portoviejo Ecuador

b Civil Engineer, Magister in Education the Universidad Tecnica de Manabi, Portoviejo Ecuador

c Graduate of the degree and Civil Engineering of Faculty of Mathematical, Physical and Chemical Sciences, Universidad Tecnica de Manabi, Portoviejo Ecuador

d Graduate of the degree and Civil Engineering of Faculty of Mathematical, Physical and Chemical Sciences, Universidad Tecnica de Manabi, Portoviejo Ecuador

e Civil Engineering of Faculty of Mathematical, Physical and Chemical Sciences, Universidad Tecnica de Manabi, Portoviejo Ecuador 


\section{Contents}

Abstract

1. Introduction

2. Research Method

3. Results and Analysis

4. Conclusion

Conflict of interest statement and funding sources...

Statement of authorship

Acknowledgements

References

Biography of Authors

\section{Introduction}

Currently there are many road problems and one of the causes of this is the inadequate material that we use on site, that is why this research is born, to find through laboratory test studies and information sources a material that can provide the Engineers the guidelines and appropriate technical criteria to efficiently design the layers of unpaved and paved roads or roads, providing them with structural stability to achieve their best possible performance in terms of technical-economic efficiency for the benefit of society as a whole [1].

The engineering of pavements has been carried out for several years, existing regulations that must be complied with in its construction, in addition to books that have been published for the teaching of the subject as basic texts [2] to specialized information in the field of road pavements. finds very dispersed, but also not at all sites pavement behavior is the same so there is a need to continue research on the subject.

In Portoviejo, province of Manabí, a study was made of different quarries to extract material for the construction of roads, the objective of this work is to characterize the clays of the quarries of Megarok and San José and compare them with material mixed with asphalt to determine the characteristics of these for the construction of resistant roads [2].

Other investigations have been developed with the objective of evaluating the quality of clays for pavements and other types of construction [4], in this investigation different tests were performed in the laboratory with natural soil introducing different percentages of lime, with the results verified, that with $6 \%$ of lime is adequate since they reach low levels of expansiveness, which ensures a good stabilization.

Therefore, one of the lines of the investigation in the materials is to achieve that it fulfills the characteristics of base and/or sub-base with the stabilization of soils and that allows an easy application, economy and a better adhesion with the stony materials, which presents a level of relevance among Civil Engineers in the professional field of design and construction of pavement structures [2].

The main structures that form the bases and sub-bases are determined by the use of granular materials treated with asphalt emulsions and cement in the pavements, this use improves the adhesion of the asphalt with the main granular material and the increase of the resistance of the base and sub-base in the useful life of the asphalt folder [3].

The purpose of our research is to corroborate with trial studies reliable, optimal information, with quick and economical solutions when using this material as an alternative, validated by compliance and proper functioning in accordance with the specifications proposed by the MTOP (Ministry of Transport and Public Works), for the construction of roads [7].

\section{Research Method}

A field study was conducted by extracting the samples from the San José and AGRE SA quarries, which were taken to the laboratory to perform the natural humidity, Atterberg limit, granulometry, abrasion, Proctor, California Bearing Ratio (CBR) [8].

The necessary equipment was used to prepare the samples (tare, cylinder, Proctor, CBR, large house, router, among others, to check if the results obtained in the process of carrying out tests complied with the granulometric standards and AASTHO, for base or subbase, but it was possible to demonstrate that the 
material by itself did not comply with the regulations, so it was valued to mix it with the asphalt emulsion and proceed to carry out the same studies to verify if they comply with the stipulations of the specific standards with the purpose of which are of better results.

\section{Results and Analysis}

Quarries that are currently used in Portoviejo are: San José and AGRE S.A. found in the Picoazá parish of the Portoviejo canton.

The granular material is formed by a set of solid particles of different sizes, where its coarse particles from a mineral skeleton once compacted and whose resistance depends mainly on internal friction. Internally this type of matter presents in its composition the three states: solid, formed by the material coming from the stone; liquid, due to the presence of water; and gaseous, through intergranular spaces filled with air [4].

The material called soil-cement is obtained by the intimate mixture of a sufficiently disaggregated soil with cement, water, and other possible additions, followed by a suitable compaction and curing. In this way, the loose material becomes another hardened, much more resistant [5].

The purpose of our research is to corroborate with trial studies reliable, optimal information, with quick and economical solutions when using this material as an alternative, validated by compliance and proper functioning in accordance with the specifications proposed by the MTOP (Ministry of Transport and Public Works), for the construction of roads.

The research work includes the characterization of the materials that are used within the canton for the construction of the roads and that are part of the bases and sub-bases of the pavements, with the aim of identifying the possible problems of quality and non-compliance of the specifications.

Two types of evaluations were made from the selection of material from the selected quarries. These were mixed to know if the standards were met to be used in the pavement of the city of Portoviejo as a base or subbase [9], shown in table 1.

Table 1

Amount of clay mixed with different material

\begin{tabular}{lccc}
\hline \multicolumn{1}{c}{ Quarry } & Clay $(\mathrm{g})$ & Material & Asphalt emulsion $(\mathrm{g})$ \\
\hline AGRE S.A. & 6000 & Ballast & $7 \%$ \\
San José & 6000 & Ballast & $7 \%$ \\
\hline
\end{tabular}

For the study of the sub-base, sieves of different sizes $(76.2,50.4,38.1,4.75,0.425,0.075 \mathrm{~mm})$ were used to see if the clays complied with the regulations for the bases and sub-bases. They were divided into three classes to know the maximum and minimum values and be compared with the results obtained from the mixtures for the sub-base. Table 2 shows the granulometric specifications of the AASTHO standards [10] and the graph of figure 1 shows the results obtained for class 1 , where the maximum and minimum percentage values appear compared to the samples passed in each sieve.

Table 2

Granulometric specifications of the sub-base

\begin{tabular}{ccccccc}
\hline \multirow{2}{*}{ Sieves } & \multicolumn{2}{c}{ Class 1 } & \multicolumn{2}{c}{ Class 2 } & \multicolumn{2}{c}{ Class 3 } \\
& Max & Min & Max & Min & Max & Min \\
\hline 76,2 & & & & & 100 & 100 \\
50,4 & 100 & 100 & 100 & 100 & & \\
38,1 & 70 & 30 & 70 & 30 & 70 & 30 \\
4,75 & 35 & 10 & 40 & 15 & & \\
0,425 & 15 & 0 & 20 & 0 & 20 & 0 \\
0,075 & & & & & \\
\hline
\end{tabular}

Meza, M. I. Z., Veliz, E. A. R., Mendoza, C. A. V., Delgado, R. A. C., \& Ormaza, G. F. (2018). Comparison of studies through laboratory tests to loan material (ballast) of San Jose and AGRE S.A. quarries treated with asphalt emulsion or cement. IJPSE, 2(2), 50-67. https://doi.org/10.29332/ijpse.v1n2.146 


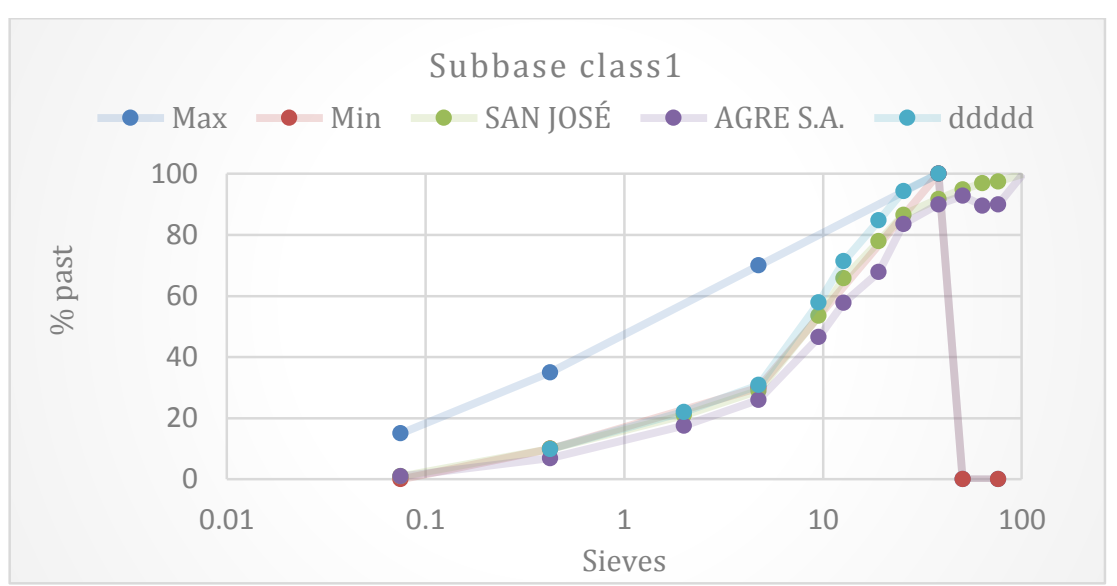

Figure 1. Maximum and minimum values obtained in sub-base class 1

It is conceivable that the sample of clays from the quarries studied does not comply with the AASTHO standards, demonstrating that another procedure must be carried out to be used in the pavement structure.

Figure 2 (A) shows the results for class 2 and figure 2 (B) for class 3. With thicker screens, it also does not comply with AASTHO standards
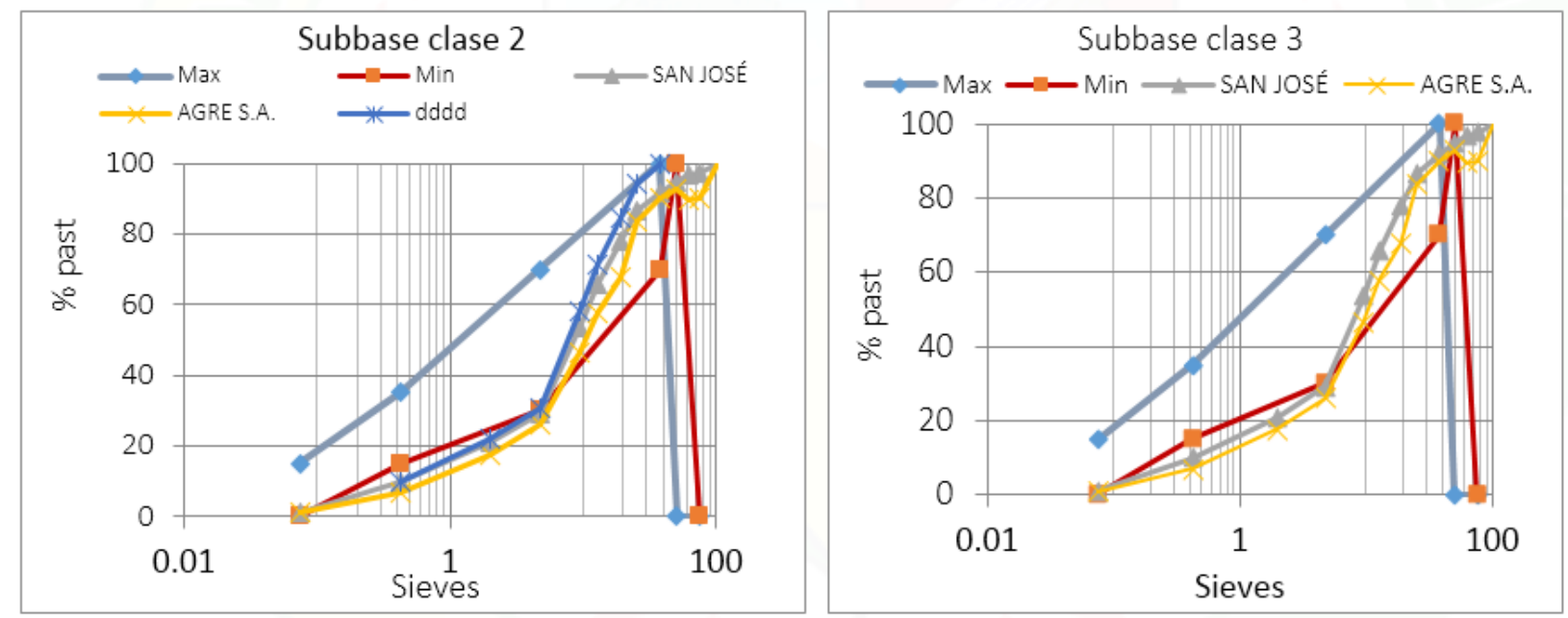

Figure 2. Deductions obtained in class 2 (a) and class 3 (b)

In figure 3 the 3 classes of the sub-base and the AASTHO regulations are revealed observing that it does not comply with the specific percentages. 


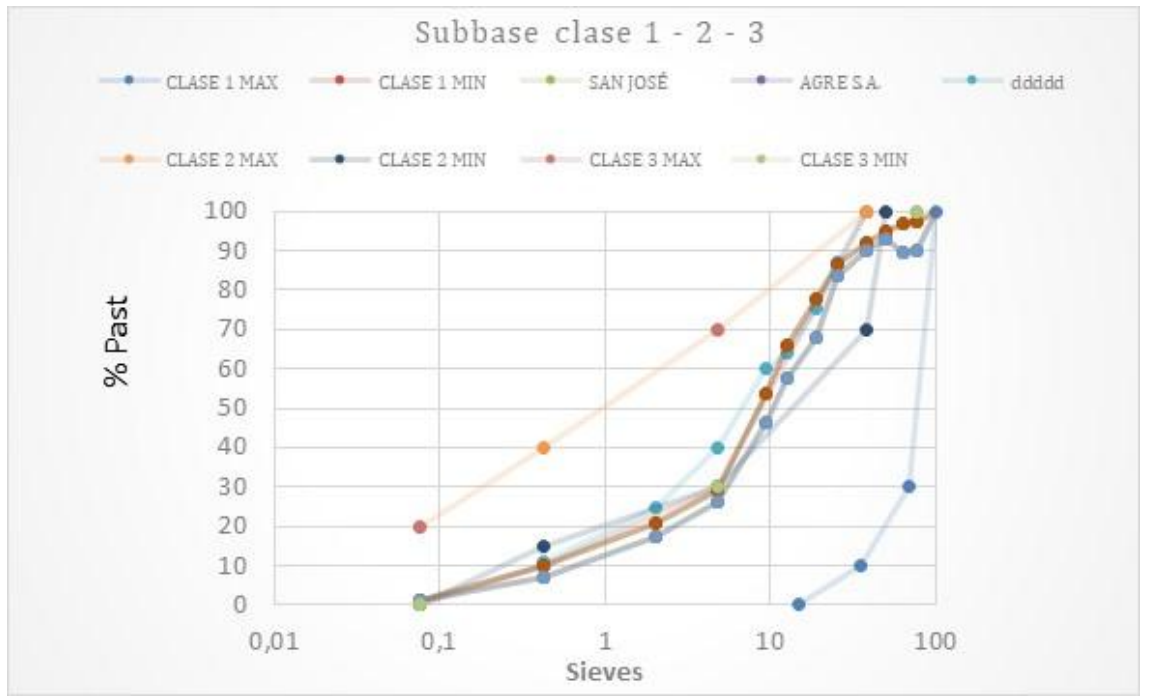

Figure 3. Regulations with the 3 sub-base classes

In table 3 shows the different granulometric specifications of the base.

Table 3

Specifications of the base

\begin{tabular}{|c|c|c|}
\hline \multirow[t]{2}{*}{ Sieve } & \multicolumn{2}{|c|}{$\begin{array}{l}\text { Percentage by weight that passes through the shades } \\
\text { of square mesh }\end{array}$} \\
\hline & Kind A & Kind B \\
\hline $2 "(50.4 \mathrm{~mm})$ & 100 & -- \\
\hline $11 / 2 "(38.1 \mathrm{~mm})$ & $70-100$ & 100 \\
\hline $1^{\prime \prime}(25.4 \mathrm{~mm})$ & $55-85$ & $70-100$ \\
\hline $3 / 4^{\prime \prime}(19.05)$ & $50-80$ & $60-90$ \\
\hline $3 / 8^{\prime \prime}(9.525 \mathrm{~mm})$ & $35-60$ & $47-75$ \\
\hline $\mathrm{N}^{\circ} 4(4.75 \mathrm{~mm})$ & $25-50$ & $30-60$ \\
\hline $\mathrm{N}^{\circ} 10(2.00 \mathrm{~mm})$ & $20-40$ & $20-50$ \\
\hline $\mathrm{N}^{\circ} 40(0.425 \mathrm{~mm})$ & $10-25$ & $10-25$ \\
\hline $\mathrm{N}^{\circ} 200(0.075 \mathrm{~mm})$ & $2-12$ & $2-12$ \\
\hline
\end{tabular}

Figure 4 (A) shows the results for type A and in figure 4 (B) for base type B. With thicker sieves not complying with AASTHO regulations

Meza, M. I. Z., Veliz, E. A. R., Mendoza, C. A. V., Delgado, R. A. C., \& Ormaza, G. F. (2018). Comparison of studies through laboratory tests to loan material (ballast) of San Jose and AGRE S.A. quarries treated with asphalt emulsion or cement. IJPSE, 2(2), 50-67. https://doi.org/10.29332/ijpse.v1n2.146 

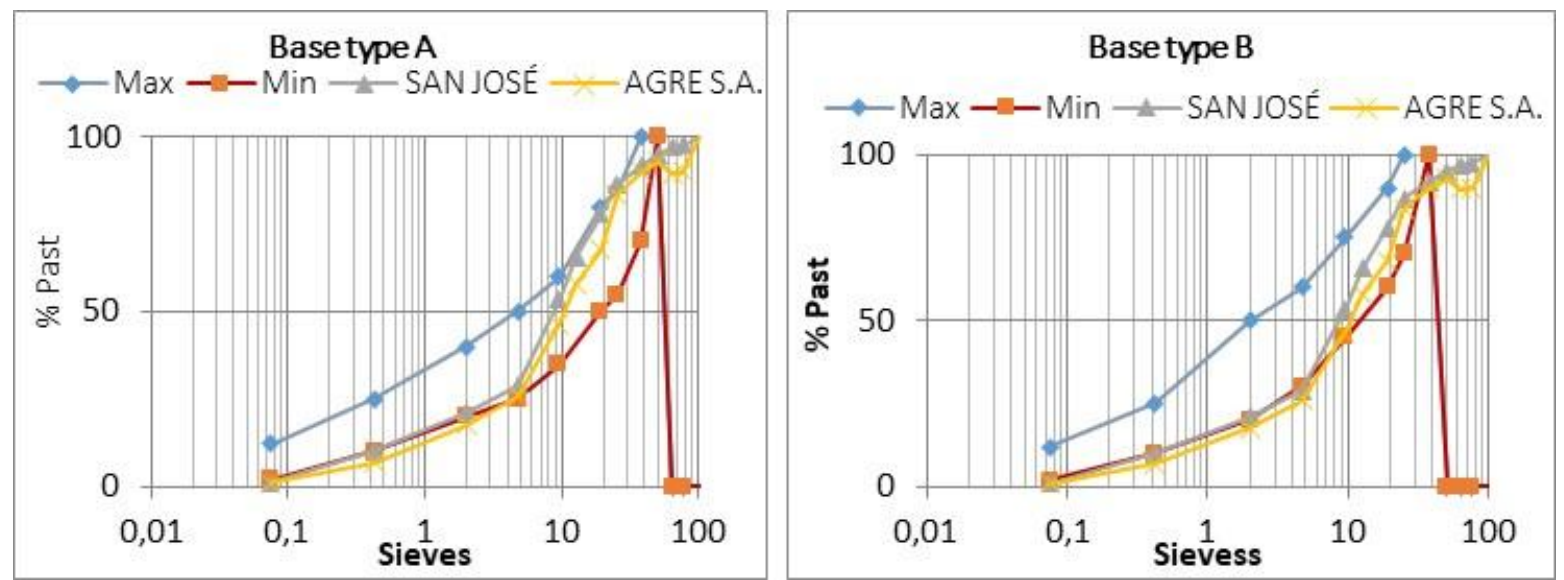

Figure 4. Maximum and minimum values obtained in the base type $\mathrm{A}$ and type $\mathrm{B}$

Figure 5 indicates the description of the bases in type (A) and (B) that do not comply with the granulometric standards, so that the strip is under the granulometric spindle, therefore it can not be used for pertinent purposes.

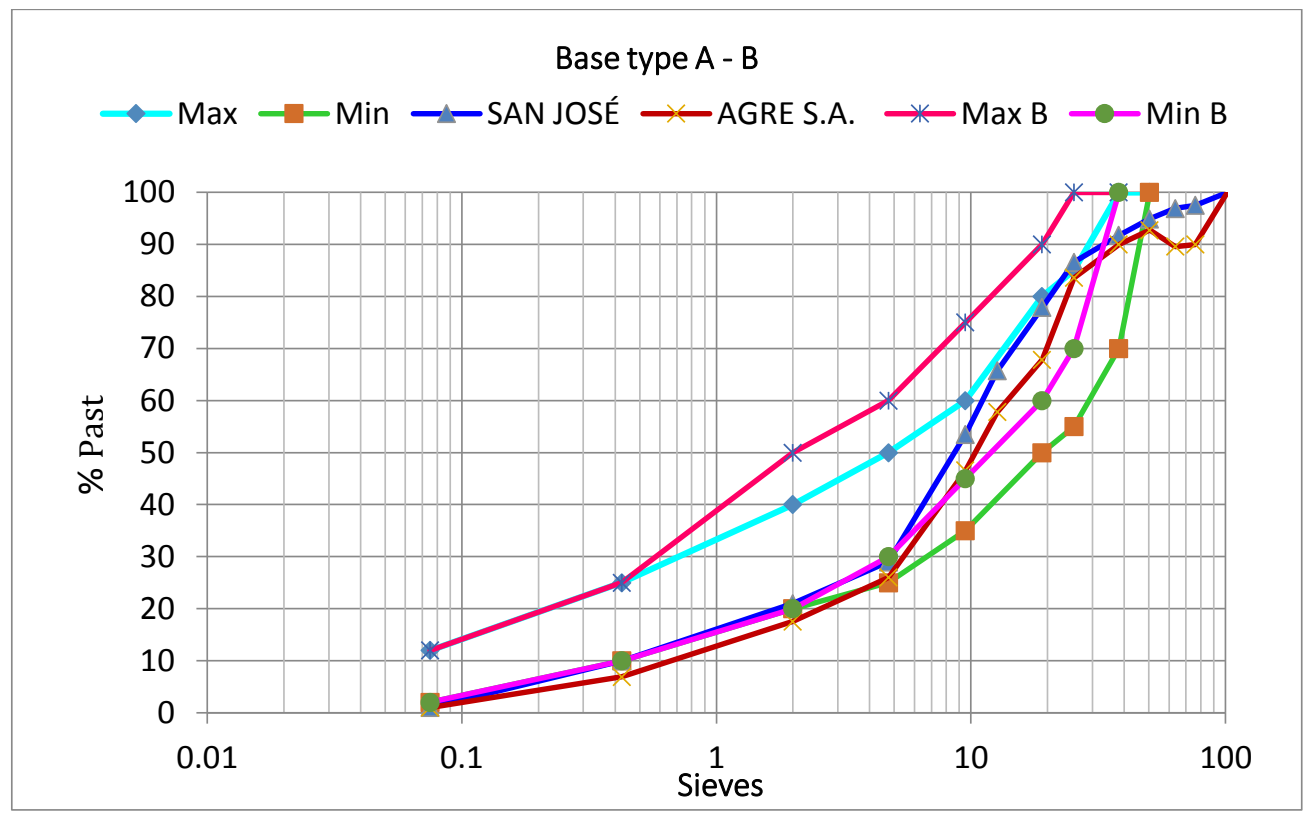

Figure 5. Regulations for the two types of bases

When this investigation was prepared, the granulometry of San José and AGRE S.A. it is verified that both cases fail with the specifications of the sub-base material for different classes $(1,2,3)$. In the class 1 sub-base, the observed values of both quarries coincide approximately with the minimum value of the granulometric use for sizes smaller than the $3 / 8$ in $(9,525 \mathrm{~mm})$ sieve, with the past percentages being much lower for the spindle, but as can be observed in figure 5 , the valuations have obtained a good result, verifying its usefulness in the construction of the bases and sub-base of the roads 


\section{Conclusion}

As stipulated in the technical specifications, the comparison made between the materials of the quarries "San José" and "AGRE SA.", It was considered that the quarry "San José" to be subjected to the stabilization with emulsion. An optimum percentage of $7 \%$ emulsion was established immediately or dry with a CBR of 61.77 and subjected to unfavorable conditions of saturation at 24 hours with a percentage of $7 \%$ and a CBR of 42.13 to 48 hours, and a adequate percentage of 5\% in a CBR of 42.55 explaining all the results to the fulfillment of the specifications proposed by the MTOP for the operation of a sub-base getting to improve the resistance characteristics of the study material.

Conflict of interest statement and funding sources

The authors declared that they have no competing interest. The study was financed by personal funding.

Statement of authorship

The authors have a responsibility for the conception and design of the study. The authors have approved the final article.

\section{Acknowledgments}

Special thanks are due to the students who have collaborated to carry out the research in the proposed study areas.

Meza, M. I. Z., Veliz, E. A. R., Mendoza, C. A. V., Delgado, R. A. C., \& Ormaza, G. F. (2018). Comparison of studies through laboratory tests to loan material (ballast) of San Jose and AGRE S.A. quarries treated with asphalt emulsion or cement. IJPSE, 2(2), 50-67. https://doi.org/10.29332/ijpse.v1n2.146 


\section{References}

1. Montejo Fonseca, A. (2008). Ingeniería de pavimentos T. 1: Fundamentos, estudios básicos y diseño. View in (Google Scholar)

2. Fonseca, A. M. (1999). Ingeniería de pavimentos para carreteras. Ciencia e Ingeniería Neogranadina, 7 , 79-92.

View in (Google Scholar)

3. Zambrano, M. M., \& Kolter, R. (1996). GASPing for life in stationary phase. Cell, 86(2), 181-184.

View in (Google Scholar)

4. Hernández, E. H. O., Moncayo, E. H. O., Sánchez, L. K. M., \& de Calderero, R. P. (2017). Behavior of Clayey Soil Existing in the Portoviejo Canton and Its Neutralization Characteristics. International Research Journal of Engineering, IT and Scientific Research (IRJEIS), 3(6), 1-10.

View in (Google Scholar)

5. Ancade, A. Ieca.(2008). Manual de estabilizacion de suelos con cemento o cal.

View in (Google Scholar)

6. de Pedro Carracedo, J., \& Méndez, C. L. M. (2012). Realidad Aumentada: Una Alternativa Metodológica en la Educación Primaria Nicaragüense. IEEE-RITA, 7(2), 102-108.

View in (Google Scholar)

7. Salas-Provance, M. B., Erickson, J. G., \& Reed, J. (2002). Disabilities as viewed by four generations of one Hispanic family. American Journal of Speech-Language Pathology, 11(2), 151-162.

View in (Google Scholar)

8. González, M. C., Garcia-Barba, J., Blázquez, L. B., Tomás-Jover, R., Tenza-Abril, A. J., Abellán, J. V., ... \& García, D. B. (2015). Implementación del contenido de las asignaturas del Máster de Ingeniería Geológica. In Investigación y Propuestas Innovadoras de Redes UA para la Mejora Docente (pp. 725-747). Instituto de Ciencias de la Educación.

View in (Google Scholar)

9. BRACHO, C. (2005). Cuaderno FIRP S366C Emulsiones asfálticas. Mérida, Venezuela: Universidad de los Andes, Facultad de Ingeniería, Escuela de Ingeniería Química.

View in (Google Scholar)

10. Roa, A. E. P., Perdomo, M. D. P. B., Sánchez, H. A. S., Pineda, M. O. P., Soto, É. R., \& Patiño, L. A. G. (2004). ¿ Cómo perciben los estudiantes de pregrado de la Facultad de Medicina de la Universidad Nacional de Colombia su proceso de evaluación académica?. Revista de la Facultad de Medicina, 52(2), 98-114.

View in (Google Scholar)

11. Cadenas, E., Rodríguez, Á. A., \& Jaramillo, J. J. (2017). Pavimentos permeables. Una aproximación convergente en la construcción de vialidades urbanas y en la preservación del recurso agua. CIENCIA ergo-sum, 24(2), 173-180.

View in (Google Scholar) 


\section{Biography of Authors}

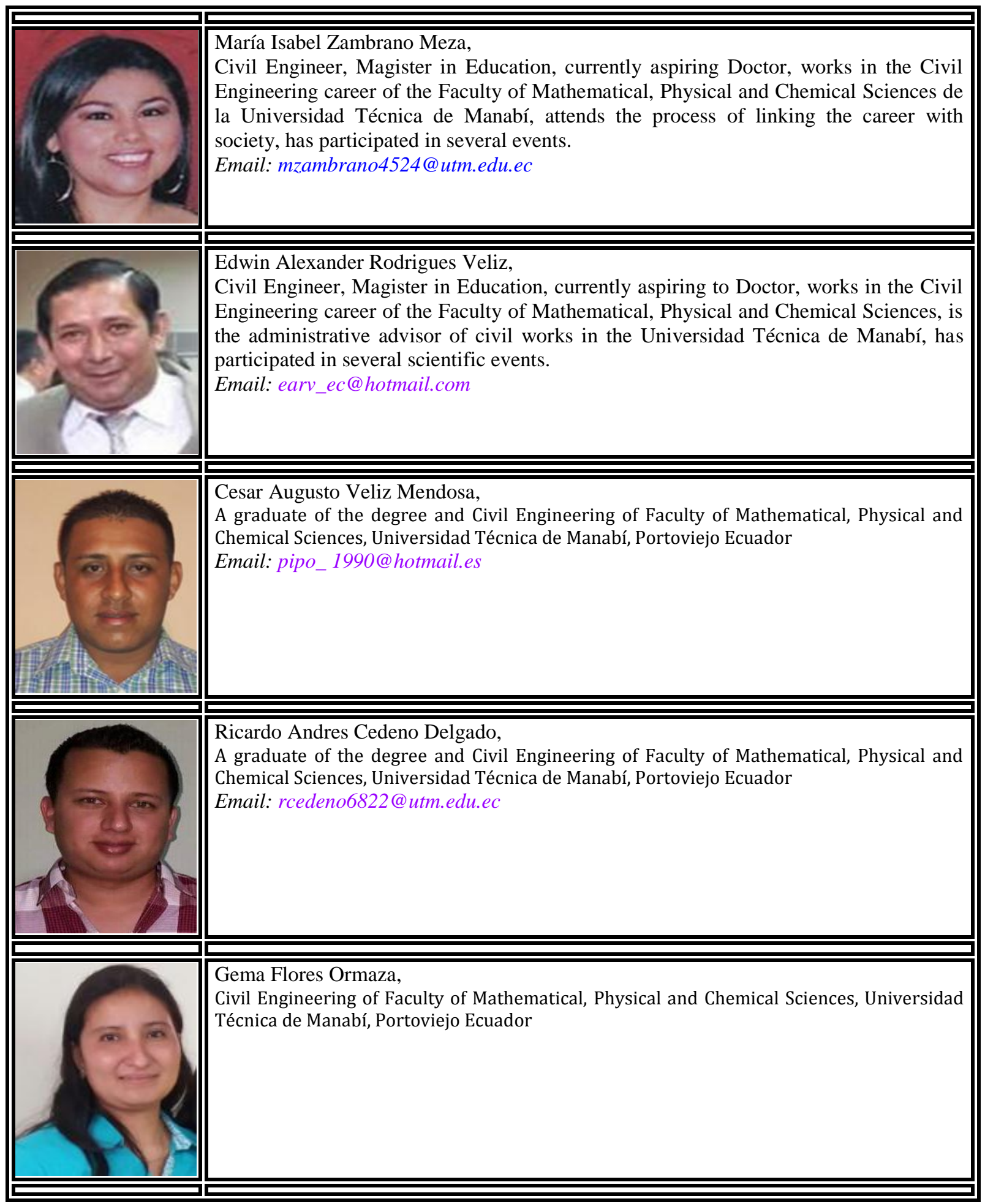

Meza, M. I. Z., Veliz, E. A. R., Mendoza, C. A. V., Delgado, R. A. C., \& Ormaza, G. F. (2018). Comparison of studies through laboratory tests to loan material (ballast) of San Jose and AGRE S.A. quarries treated with asphalt emulsion or cement. IJPSE, 2(2), 50-67. https://doi.org/10.29332/ijpse.v1n2.146 